\title{
NO Scavenging through Reductive Nitrosylation of Ferric Mycobacterium tuberculosis and Homo sapiens Nitrobindins
}

\author{
Giovanna De Simone ${ }^{1}$, Alessandra di Masi ${ }^{1} \mathbb{D}$, Chiara Ciaccio $^{2}$, Massimo Coletta ${ }^{2}$ \\ and Paolo Ascenzi 1,3,*(D) \\ 1 Department of Sciences, Roma Tre University, Viale Guglielmo Marconi 446, 00146 Roma, Italy; \\ giovanna.desimone@uniroma3.it (G.D.S.); alessandra.dimasi@uniroma3.it (A.d.M.) \\ 2 Department of Clinical Sciences and Translational Medicine, University of Roma "Tor Vergata", \\ Via Montpellier 1, I-00133 Roma, Italy; chiara.ciaccio@uniroma2.it (C.C.); coletta@seneca.uniroma2.it (M.C.) \\ 3 Interdepartmental Laboratory of Electron Microscopy, Roma Tre University, Via della Vasca Navale 79, \\ I-00146 Roma, Italy \\ * Correspondence: ascenzi@uniroma3.it; Tel.: +39-06-5733-3621
}

Received: 30 September 2020; Accepted: 1 December 2020; Published: 10 December 2020

\begin{abstract}
Ferric nitrobindins ( $\mathrm{Nbs}$ ) selectively bind $\mathrm{NO}$ and catalyze the conversion of peroxynitrite to nitrate. In this study, we show that NO scavenging occurs through the reductive nitrosylation of ferric Mycobacterium tuberculosis and Homo sapiens nitrobindins ( $\mathrm{Mt}-\mathrm{Nb}(\mathrm{III})$ and $\mathrm{Hs}-\mathrm{Nb}(\mathrm{III})$, respectively). The conversion of $M t-\mathrm{Nb}$ (III) and $H s-\mathrm{Nb}$ (III) to $M t-\mathrm{Nb}$ (II)-NO and $H s-\mathrm{Nb}$ (II)-NO, respectively, is a monophasic process, suggesting that over the explored $\mathrm{NO}$ concentration range (between $2.5 \times 10^{-5}$ and $1.0 \times 10^{-3} \mathrm{M}$ ), NO binding is lost in the mixing time (i.e., $\mathrm{NO}_{\mathrm{on}_{\mathrm{on}}} \geq 1.0 \times 10^{6} \mathrm{M}^{-1} \mathrm{~s}^{-1}$ ). The pseudo-first-order rate constant for the reductive nitrosylation of $\mathrm{Mt}-\mathrm{Nb}$ (III) and $\mathrm{Hs}-\mathrm{Nb}$ (III) (i.e., $k$ ) is not linearly dependent on the NO concentration but tends to level off, with a rate-limiting step (i.e., $k_{\text {lim }}$ ) whose values increase linearly with $\left[\mathrm{OH}^{-}\right]$. This indicates that the conversion of $\mathrm{Mt}-\mathrm{Nb}(\mathrm{III})$ and $H s-\mathrm{Nb}$ (III) to $M t-\mathrm{Nb}$ (II)-NO and $H s-\mathrm{Nb}$ (II)-NO, respectively, is limited by the $\mathrm{OH}^{-}$-based catalysis. From the dependence of $k_{\lim }$ on $\left[\mathrm{OH}^{-}\right]$, the values of the second-order rate constant $k_{\mathrm{OH}-}$ for the reductive nitrosylation of $\mathrm{Mt}-\mathrm{Nb}$ (III)-NO and $\mathrm{Hs}-\mathrm{Nb}$ (III)-NO were obtained $\left(4.9( \pm 0.5) \times 10^{3} \mathrm{M}^{-1} \mathrm{~s}^{-1}\right.$ and $6.9( \pm 0.8) \times 10^{3} \mathrm{M}^{-1} \mathrm{~s}^{-1}$, respectively). This process leads to the inactivation of two NO molecules: one being converted to $\mathrm{HNO}_{2}$ and another being tightly bound to the ferrous heme-Fe(II) atom.
\end{abstract}

Keywords: nitrobindin; heme-protein; NO scavenging; reductive nitrosylation

\section{Introduction}

Globins are globular ferrous heme-proteins that have evolved across all domains of life to sense, bind, store, and transport diatomic gases, as well as to catalyze the synthesis and scavenging of reactive nitrogen and oxygen species [1-3]. They are composed of six or four $\alpha$-helical segments, which are shaped around heme with a $3 / 3$ - or $2 / 2$-fold. In $3 / 3$ globins, the A, B, and $\mathrm{E} \alpha$-helices face the heme distal side and the $\mathrm{F}, \mathrm{G}$, and $\mathrm{H} \alpha$-helices are in front of the proximal side. In 2/2 globins, two antiparallel pairs of $\alpha$-helices $\mathrm{B} / \mathrm{E}$ and $\mathrm{G} / \mathrm{H}$ encompass the heme [2-6].

In contrast, nitrophorins (NPs) and nitrobindins (Nbs) are the only all- $\beta$-barrel heme-proteins displaying a ferric heme-Fe atom [7-13]. The eight-stranded $\beta$-barrel NPs have been described only in the hematophagous bug Rhodnius prolixus (Rp-NP), which stores NO in its salivary glands. When the insect feeds on its victim, its saliva is pumped into the victim's tissues and NO is released, with consequent vasodilation. Then, $R p$-NPs bind the host's histamine, reducing inflammation and 
itch [14-19]. In contrast, NPs from the bedbug Cimex lectularius display a mixed $\alpha$-helical/ $\beta$-barrel-fold, highlighting the remarkable evolution of proteins that assist insects in blood feeding [20].

The physiological role(s) of the evolutionary conserved 10-stranded $\beta$-barrel $\mathrm{Nbs}$ is still uncertain [10-13]. Ferric Arabidopsis thaliana $\mathrm{Nb}$ has been hypothesized to transport and to release $\mathrm{NO}$ at the infection site after wounding and pathogenic infections; then, $\mathrm{NO}$ may reduce $\mathrm{O}_{2}$ to the superoxide radical, increasing pathogen burden [10]. Moreover, ferric Mycobacterium tuberculosis and Homo sapiens $\mathrm{Nbs}(\mathrm{Mt}-\mathrm{Nb}(\mathrm{III})$ and $\mathrm{Hs}-\mathrm{Nb}(\mathrm{III})$, respectively) have been reported to selectively bind $\mathrm{NO}$ and to catalyze peroxynitrite scavenging, protecting both organisms from peroxynitrite-mediated nitration $[13,21]$.

Unlike monomeric NPs and bacterial and plant Nbs $[7-10,13,15,16,18], \mathrm{Hs}-\mathrm{Nb}$ corresponds to the C-terminal domain of the single-chain nuclear peroxynitrite isomerase THAP4. Interestingly, it could act as a NO sensor modulating THAP4 transcriptional function, residing at the $\mathrm{N}$-terminal modified zinc finger domain [13].

To shed light on the $\mathrm{NO}$ chemistry of $\mathrm{Nbs}$, the reductive nitrosylation of $\mathrm{Mt}-\mathrm{Nb}$ (III) and $\mathrm{Hs}-\mathrm{Nb}$ (III) has been investigated and analyzed in parallel with that of prototypical all- $\alpha$-helical heme-proteins. Interestingly, the values of the dissociation equilibrium constant for $\mathrm{NO}$ binding to $\mathrm{Mt}-\mathrm{Nb}$ (III) and $\mathrm{Hs}-\mathrm{Nb}$ (III) (i.e., $\mathrm{K}$ ) and of the second-order rate constant of the $\mathrm{OH}^{-}$-mediated conversion of $M t-\mathrm{Nb}$ (III)-NO to $M t-\mathrm{Nb}$ (II)-NO and of $H s-\mathrm{Nb}$ (III)-NO to $H s-\mathrm{Nb}$ (II)-NO (i.e., $k_{\mathrm{OH}-}$ ) are closely similar to those of all- $\alpha$-helical heme-proteins. The much faster value of the second-order rate constant for $M t-\mathrm{Nb}(\mathrm{III})$ and $H s-\mathrm{Nb}(\mathrm{III})$ nitrosylation (i.e., ${ }^{\mathrm{NO}_{k}} k_{\text {on }}$ ) is likely related to the much more open heme distal side. The present results highlight the inactivation of two NO molecules: one being converted to $\mathrm{HNO}_{2}$, and another being tightly bound to the heme-Fe(II) atom. In this respect, $\mathrm{Hs}-\mathrm{Nb}$ may act as a $\mathrm{NO} / \mathrm{O}_{2}$ sensor, modulating the transcriptional activity of THAP4.

\section{Results}

The reductive nitrosylation of ferric heme-proteins is an alkaline-driven process involving two NO molecules, one being converted to $\mathrm{HNO}_{2}$ and the other being trapped tightly to the ferrous heme-Fe atom (Scheme 1) [22-29].

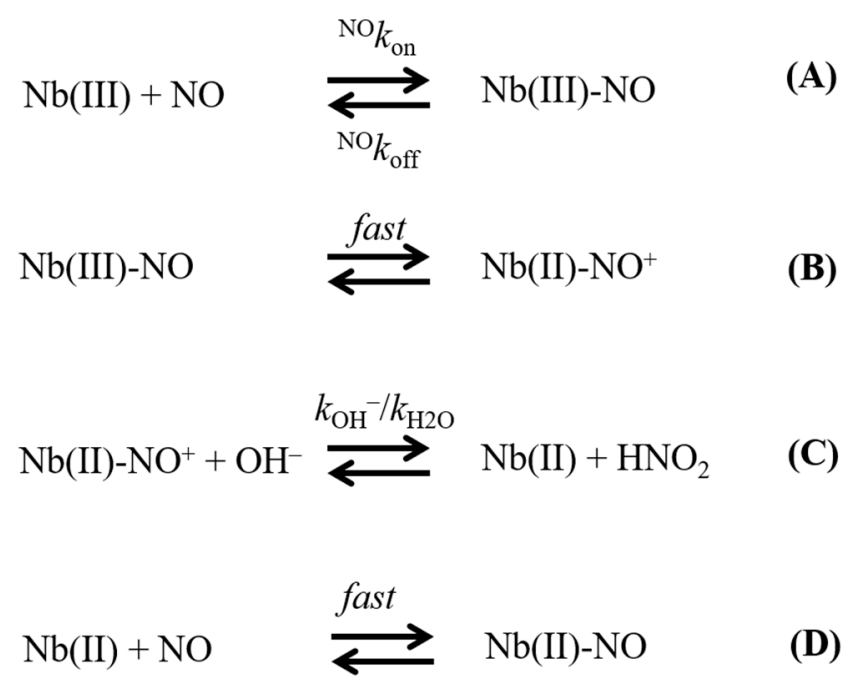

Scheme 1. Mechanism of reductive nitrosylation of $M t-\mathrm{Nb}(\mathrm{III})$ and $H s-\mathrm{Nb}(\mathrm{III})$.

At pH 7.0 and $22.0^{\circ} \mathrm{C}, \mathrm{Mt}-\mathrm{Nb}(\mathrm{III})$ and $\mathrm{Hs}-\mathrm{Nb}(\mathrm{III})$ reversibly bind $\mathrm{NO}$ [13], whereas between pH 7.8 and $9.2\left(T=20.0^{\circ} \mathrm{C}\right)$, both $\mathrm{Nbs}$ undergo irreversible reductive nitrosylation (i.e., NO-dependent formation of $\mathrm{Nb}$ (II)-NO) (present study). In fact, $M t-\mathrm{Nb}$ (II)- $\mathrm{NO}$ and $H s-\mathrm{Nb}$ (II)-NO convert to $\mathrm{Mt}-\mathrm{Nb}$ (II) and $H s-\mathrm{Nb}$ (II) instead of $\mathrm{Mt}-\mathrm{Nb}$ (III) and $H s-\mathrm{Nb}$ (III) by pumping off $\mathrm{NO}$. 
Upon mixing, $M t-\mathrm{Nb}(\mathrm{III})$ and $H s-\mathrm{Nb}(\mathrm{III})$ with the $\mathrm{NO}$ solutions, the absorbance changes of $M t-\mathrm{Nb}$ (III) and $H s-\mathrm{Nb}$ (III) nitrosylation (i.e., $\mathrm{Mt}$ - $\mathrm{Nb}$ (III)- $\mathrm{NO}$ and $H s-\mathrm{Nb}$ (III)-NO formation; Scheme $1 \mathrm{~A}$ ) are likely lost in the dead-time of the rapid-mixing stopped-flow apparatus ( $\sim \mathrm{ms})$, as expected over this NO concentration range (spanning between $2.5 \times 10^{-5}$ and $1.0 \times 10^{-3} \mathrm{M}$ ) on the basis of the reported $\mathrm{NO}_{k_{\text {on }}}$ values [13] (Table 1). As a matter of fact, immediately after mixing (i.e., within the first $10 \mathrm{~ms}$ ), the absorbance spectra are already those corresponding to $\mathrm{Mt}-\mathrm{Nb}$ (III)-NO and $\mathrm{Hs}-\mathrm{Nb}(\mathrm{III})-\mathrm{NO}$. Then, the absorbance spectra of $M t-\mathrm{Nb}(\mathrm{III})-\mathrm{NO}$ and $\mathrm{Hs}-\mathrm{Nb}$ (III)-NO gradually change to those of $M t-\mathrm{Nb}(\mathrm{II})-\mathrm{NO}$ and $\mathrm{Hs}-\mathrm{Nb}(\mathrm{II})-\mathrm{NO}$. Accordingly, the static difference absorbance spectra of $M t-\mathrm{Nb}(\mathrm{III})$ minus $M t-\mathrm{Nb}$ (II)-NO and $H s-\mathrm{Nb}$ (III) minus $H s-\mathrm{Nb}$ (II)-NO, obtained by keeping the $M t-\mathrm{Nb}$ (III) and $H s-\mathrm{Nb}$ (III) solutions under $\mathrm{NO}$ at $p=760.0 \mathrm{~mm} \mathrm{Hg}$, differ from the difference absorbance spectra obtained after rapid-mixing the $M t-\mathrm{Nb}(\mathrm{III})$ and $H s-\mathrm{Nb}(\mathrm{III})$ solutions with the $\mathrm{NO}$ solutions, since in the last case they correspond to those of $M t-\mathrm{Nb}$ (III)- $\mathrm{NO}$ minus $M t-\mathrm{Nb}$ (II)- $\mathrm{NO}$ and $H s-\mathrm{Nb}$ (III)-NO minus $\mathrm{Hs}-\mathrm{Nb}$ (II)-NO (Figures $1 \mathrm{~A}$ and 2A, respectively). This confirms that the observed time courses (Figures $1 \mathrm{~B}$ and 2B, respectively) reflect the conversion of $M t-\mathrm{Nb}$ (III)-NO to $M t-\mathrm{Nb}(\mathrm{II})-\mathrm{NO}$ and of $H s-\mathrm{Nb}(\mathrm{III})-\mathrm{NO}$ to $H s-\mathrm{Nb}(\mathrm{II})-\mathrm{NO}$.

Table 1. Values of $\mathrm{NO}_{k_{\mathrm{On}}}, K$, and $k_{\mathrm{OH}-}$ for the reductive nitrosylation of ferric heme-proteins.

\begin{tabular}{|c|c|c|c|}
\hline Heme-Protein & $\mathrm{NO}_{k_{\mathrm{on}}}\left(\mathrm{M}^{-1} \mathrm{~s}^{-1}\right)$ & $K(\mathrm{M})$ & $k_{\mathrm{OH}-}\left(\mathrm{M}^{-1} \mathrm{~s}^{-1}\right)$ \\
\hline$M t-\mathrm{Nb}$ & $1.8 \times 10^{6 \mathrm{a}}$ & $5.2 \times 10^{-5 b}$ & $4.9 \times 10^{3 c}$ \\
\hline $\mathrm{Hs}-\mathrm{Nb}$ & $1.1 \times 10^{6} \mathrm{a}$ & $5.3 \times 10^{-5 d}$ & $6.9 \times 10^{3 c}$ \\
\hline$M t-\operatorname{trHbN}$ & $1.4 \times 10^{5 \mathrm{e}}$ & $1.4 \times 10^{-5 \mathrm{e}}$ & $1.7 \times 10^{2 \mathrm{f}}$ \\
\hline$M t-\operatorname{trHbO}$ & $9.2 \times 10^{3 \mathrm{e}}$ & $1.5 \times 10^{-5} \mathrm{e}$ & $2.4 \times 10^{2 \mathrm{f}}$ \\
\hline Cj-trHbP & $9.8 \times 10^{4} \mathrm{e}$ & $5.4 \times 10^{-5 e}$ & $9.1 \times 10^{2 \mathrm{f}}$ \\
\hline Methanosarcina acetivorans Pgb & $4.8 \times 10^{4 g}$ & $6.1 \times 10^{-5 g}$ & $2.9 \times 10^{3 \mathrm{~h}}$ \\
\hline Glycine max leg $\mathrm{Hb}$ & $1.4 \times 10^{5 \mathrm{i}}$ & $2.1 \times 10^{-5 i}$ & $3.3 \times 10^{3 j}$ \\
\hline Horse heart $\mathrm{Mb}$ & $6.8 \times 10^{4 k}$ & $1.2 \times 10^{-4 \mathrm{k}}$ & $3.9 \times 10^{21}$ \\
\hline Sperm whale $\mathrm{Mb}$ & $1.9 \times 10^{5 \mathrm{~m}}$ & $7.7 \times 10^{-5 \mathrm{~m}}$ & $3.2 \times 10^{2 n}$ \\
\hline Human $\mathrm{Hb}$ & -0 & $8.3 \times 10^{-5 p}$ & $3.2 \times 10^{3} \mathrm{p}$ \\
\hline Human Hb:Hp1-1 & $-^{\mathrm{o}}$ & $9.1 \times 10^{-5 \mathrm{q}}$ & $4.9 \times 10^{3 \mathrm{r}}$ \\
\hline Human Hb:Hp2-2 & $-^{o}$ & $1.7 \times 10^{-4 \mathrm{q}}$ & $6.7 \times 10^{3 \mathrm{r}}$ \\
\hline
\end{tabular}

\footnotetext{
a Value of ${ }^{\mathrm{NO}_{k}} k_{\text {on }}$ obtained at $\mathrm{pH} 7.0$ and $\mathrm{T}=20^{\circ} \mathrm{C}$. From [13]. ${ }^{\mathrm{b}}$ Average value, values of $K$ were obtained between pH 7.8 and 9.2 at $T=20.0{ }^{\circ} \mathrm{C}$. Present study. ${ }^{\mathrm{c}} \mathrm{T}=20.0^{\circ} \mathrm{C}$. Present study. ${ }^{\mathrm{d}}$ Average value, values of $K$ were obtained between $\mathrm{pH} 8.0$ and 9.2 at $T=20.0^{\circ} \mathrm{C}$. Present study. ${ }^{\mathrm{e}}$ Average value, values of ${ }^{\mathrm{NO}} k_{\text {on }}$ and $K$ were obtained between pH 8.4 and 9.4 at $T=20.0^{\circ} \mathrm{C}$. From [27]. ${ }^{\mathrm{f}} \mathrm{T}=20.0^{\circ} \mathrm{C}$. From [27]. ${ }^{\mathrm{g}} \mathrm{pH} 7.2$ and $22.0^{\circ} \mathrm{C}$. From [26]. ${ }^{\mathrm{h}} \mathrm{T}=22.0^{\circ} \mathrm{C}$. From [26]. ${ }^{\mathrm{i}} \mathrm{pH} 7.3$ and $\mathrm{T}=20.0^{\circ} \mathrm{C}$. From [24]. ${ }^{\mathrm{j}}$ Room temperature. From [24]. ${ }^{\mathrm{k}} \mathrm{pH} 9.2$ and $\mathrm{T}=20.0^{\circ} \mathrm{C}$. From [30]. ${ }^{1} \mathrm{~T}=20.0^{\circ} \mathrm{C}$. From [30]. ${ }^{\mathrm{m}} \mathrm{pH} 8.79$ and room temperature. From [23]. ${ }^{\mathrm{n}}$ Room temperature. From [23]. ${ }^{\circ}$ Kinetics of $\mathrm{NO}$ binding to human $\mathrm{Hb}(\mathrm{III})$, human $\mathrm{Hp} 1-1: \mathrm{Hb}(\mathrm{III})$, and human $\mathrm{Hp} 2-2: \mathrm{Hb}(\mathrm{III})$ are very fast and therefore they are lost in the mixing time $[23,28] .{ }^{\mathrm{P}}$ Room temperature. From [23]. ${ }^{\mathrm{q}} \mathrm{pH} 8.2$ and $T=20^{\circ} \mathrm{C}$. From [28]. ${ }^{\mathrm{r}} \mathrm{T}=20^{\circ} \mathrm{C}$. [28].
}

The time-courses of $\mathrm{Mt}-\mathrm{Nb}$ (III) and $\mathrm{Hs}-\mathrm{Nb}$ (III) reductive nitrosylation are monophasic for $94 \pm 6 \%$ of their course (Figures $1 \mathrm{~B}$ and 2B, respectively), corresponding to Scheme 1B-D. The values of the pseudo-first-order rate constant for $\mathrm{Mt}-\mathrm{Nb}$ (III) and $\mathrm{Hs}-\mathrm{Nb}$ (III) reductive nitrosylation (i.e., $k$ ) do not increase linearly with the NO concentration but tend to level off (Figures $1 \mathrm{C}$ and 2C, respectively), highlighting the occurrence of a fast pre-equilibrium process followed by a rate-limiting step. The analysis of data shown in Figures $1 \mathrm{C}$ and $2 \mathrm{C}$ according to Equation (3) allowed us to determine the values of the dissociation equilibrium constant for $\mathrm{Mt}-\mathrm{Nb}$ (III) and $\mathrm{Hs}-\mathrm{Nb}$ (III) nitrosylation (i.e., $K$ ), and of the first-order rate constant limiting the reductive nitrosylation process (i.e., $\left.k_{\text {lim }}\right)$. The values of $K$ are pH-independent (ranging between $4.4( \pm 0.5) \times 10^{-5}$ and $\left.5.7( \pm 0.6) \times 10^{-5} \mathrm{M}\right)($ Table 1$)$ and agree with those previously obtained at $\mathrm{pH} 7.0$ and $22.0^{\circ} \mathrm{C}$ for the reversible nitrosylation of $\mathrm{Mt}-\mathrm{Nb}$ (III) and $\mathrm{Hs}-\mathrm{Nb}$ (III) (i.e., $5.0( \pm 1.5) \times 10^{-5}$ and $\left.4.4( \pm 1.2) \times 10^{-5} \mathrm{M}\right)[13]$. 
A

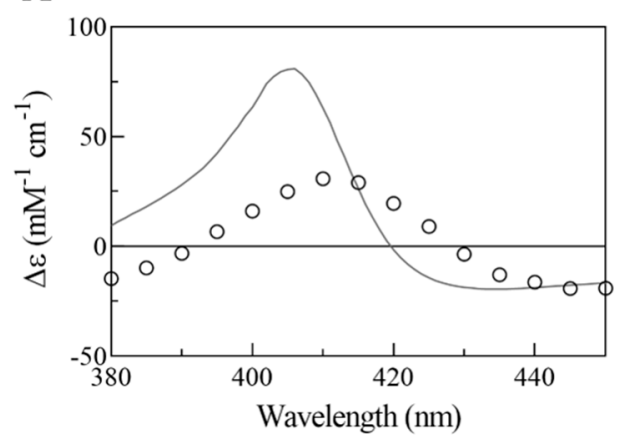

$\mathrm{C}$

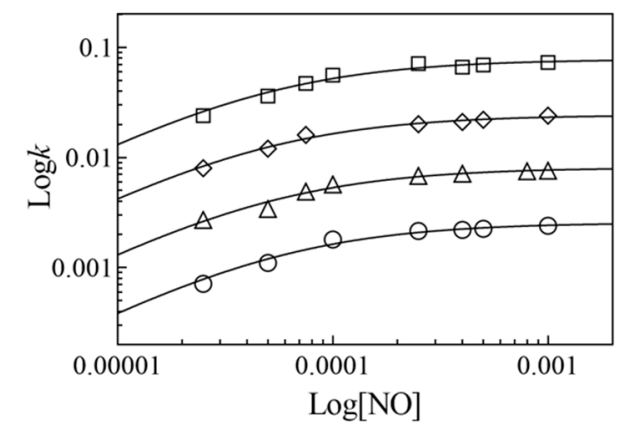

B

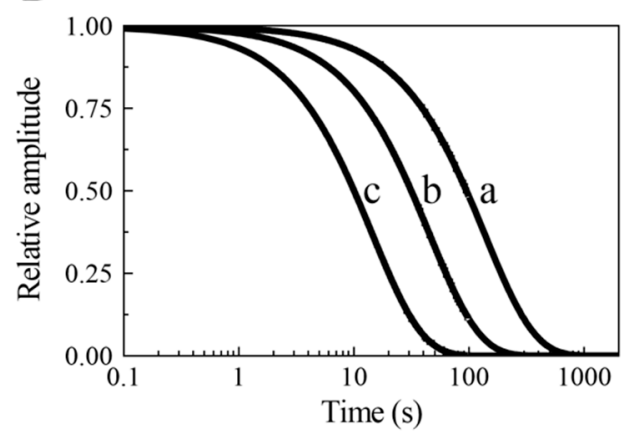

$\mathrm{D}$

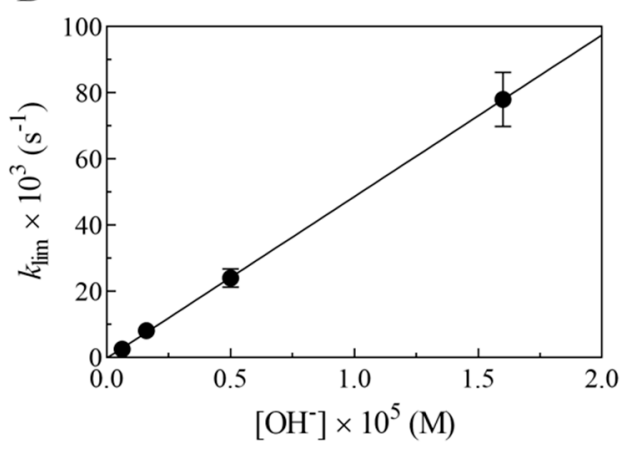

Figure 1. Reductive nitrosylation of $\mathrm{Mt}-\mathrm{Nb}$ (III) at $20.0^{\circ} \mathrm{C}$. (A) Difference optical absorption spectrum of $M t-\mathrm{Nb}$ (III) minus $\mathrm{Mt}-\mathrm{Nb}$ (II)-NO (static difference optical absorption spectrum; continuous line) and of $M t-\mathrm{Nb}(\mathrm{III})-\mathrm{NO}$ minus $\mathrm{Mt}-\mathrm{Nb}$ (II)-NO (kinetic difference optical absorption spectrum; circles) at $\mathrm{pH}$ 7.8. (B) Time course of reductive nitrosylation of $M t-\mathrm{Nb}(\mathrm{III})$ at $\mathrm{pH} 8.2$ (a), 8.7 (b), and 9.2 (c). Values of the rate constant $k$ were calculated according to Equation (1): $7.3 \times 10^{-3} \mathrm{~s}^{-1}$ (a), $2.2 \times 10^{-2} \mathrm{~s}^{-1}$ (b), and $6.9 \times 10^{-2} \mathrm{~s}^{-1}$ (c). The $\mathrm{Mt}-\mathrm{Nb}$ (III) concentration was $4.1 \times 10^{-6} \mathrm{M}$. The NO concentration was $5.0 \times 10^{-4} \mathrm{M}$. (C) Dependence of $\log k\left(\mathrm{~s}^{-1}\right)$ on $\log [\mathrm{NO}](\mathrm{M})$ at $\mathrm{pH} 7.8$ (circles), 8.2 (triangles), 8.7 (diamonds), and 9.2 (squares). The continuous lines were calculated according to Equation (3) with the following parameters: $\mathrm{pH} 7.8: \mathrm{K}=5.7( \pm 0.6) \times 10^{-5} \mathrm{M}$ and $k_{\lim }=2.5( \pm 0.3) \times 10^{-3} \mathrm{~s}^{-1}$; $\mathrm{pH}$ 8.2: $K=5.2( \pm 0.6) \times 10^{-5} \mathrm{M}$ and $k_{\lim }=8.1( \pm 0.9) \times 10^{-3} \mathrm{~s}^{-1} ; \mathrm{pH} 8.7: K=4.8( \pm 0.5) \times 10^{-5} \mathrm{M}$ and $k_{\text {lim }}=2.4( \pm 0.3) \times 10^{-2} \mathrm{~s}^{-1} ; \mathrm{pH} 9.2: K=5.0( \pm 0.6) \times 10^{-5} \mathrm{M}$ and $k_{\text {lim }}=7.8( \pm 0.9) \times 10^{-2} \mathrm{~s}^{-1}$. (D) Dependence of $k_{\lim }$ on the $\mathrm{OH}^{-}$concentration. The continuous line was calculated according to Equation (4) with $k_{\mathrm{OH}-}=4.9( \pm 0.5) \times 10^{3} \mathrm{M}^{-1} \mathrm{~s}^{-1}$. Where not shown, the error bars were smaller than the symbol.

The values of $k_{\text {lim }}$ for the reductive nitrosylation of $M t-\mathrm{Nb}(\mathrm{III})$ and $H s-\mathrm{Nb}$ (III) increase linearly with $\mathrm{pH}$ (Figures 1D and 2D, respectively). The analysis of data according to Equation (4) allowed us to determine the values of $k_{\mathrm{OH}-}$ for the $\mathrm{OH}^{-}$-catalyzed conversion of $M t-\mathrm{Nb}$ (II)- $\mathrm{NO}^{+}$to $M t-\mathrm{Nb}$ (II) and $H s-\mathrm{Nb}(\mathrm{II})-\mathrm{NO}^{+}$to $H s-\mathrm{Nb}(\mathrm{II})$, respectively, from the slope of the linear plots of $k_{\text {lim }}$ versus $\left[\mathrm{OH}^{-}\right]$ (Table 1). The intercept of the straight lines with the $y$ axis (i.e., $k_{\mathrm{H} 2 \mathrm{O}}$ ) is close to $0 \mathrm{~s}^{-1}$, indicating that $\mathrm{OH}^{-}$catalyzes the reductive nitrosylation of $\mathrm{Mt}-\mathrm{Nb}(\mathrm{III})$ and $\mathrm{Hs}-\mathrm{Nb}(\mathrm{III})$ more efficiently than $\mathrm{H}_{2} \mathrm{O}$. 
A

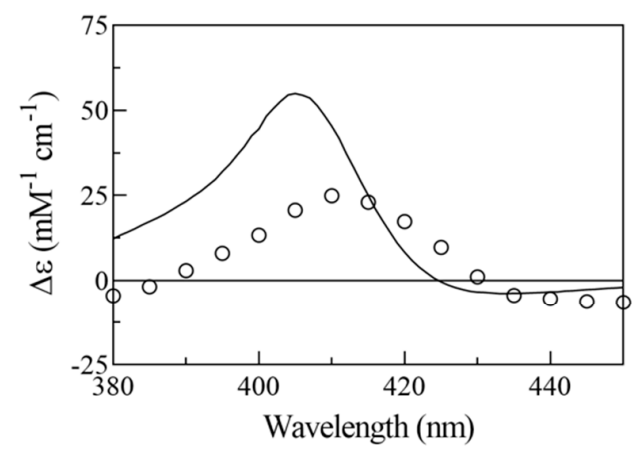

$\mathrm{C}$

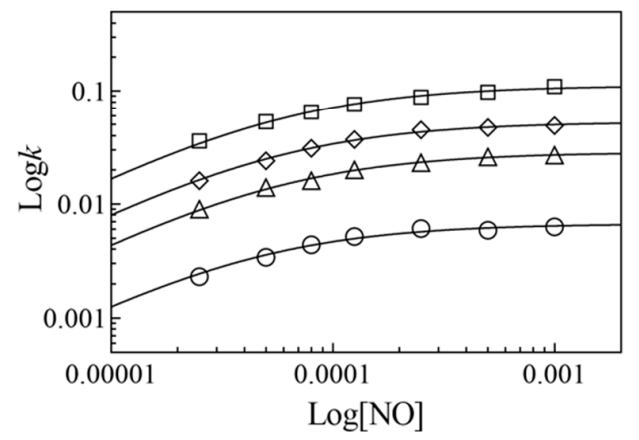

$\mathrm{B}$

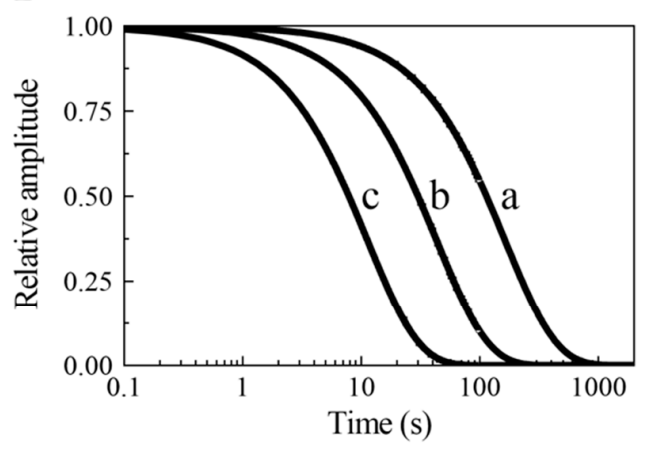

$\mathrm{D}$

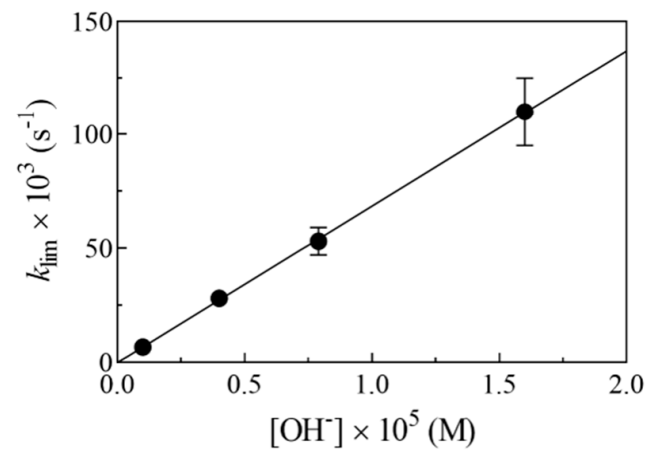

Figure 2. Reductive nitrosylation of $\mathrm{Hs}-\mathrm{Nb}$ (III) at $20.0^{\circ} \mathrm{C}$. (A) Difference optical absorption spectrum of $\mathrm{Hs}-\mathrm{Nb}$ (III) minus $\mathrm{Hs}-\mathrm{Nb}$ (II)-NO (static difference optical absorption spectrum; continuous line) and of $H s-\mathrm{Nb}(\mathrm{III})-\mathrm{NO}$ minus $\mathrm{Hs}-\mathrm{Nb}$ (II)-NO (kinetic difference optical absorption spectrum; circles) at pH 8.0. (B) Time course of reductive nitrosylation of $H s-\mathrm{Nb}(\mathrm{III})$ at $\mathrm{pH} 8.0$ (a), 8.6 (b), and 9.2 (c). Values of the rate constant $k$ were calculated according to Equation (1): $6.1 \times 10^{-3} \mathrm{~s}^{-1}$ (a), $2.3 \times 10^{-2} \mathrm{~s}^{-1}$ (b), and $8.8 \times 10^{-2} \mathrm{~s}^{-1}$ (c). The $\mathrm{Hs}-\mathrm{Nb}$ (III) concentration was $3.5 \times 10^{-6} \mathrm{M}$. The $\mathrm{NO}$ concentration was $5.0 \times 10^{-4} \mathrm{M}$. (C) Dependence of $\log k\left(\mathrm{~s}^{-1}\right)$ on $\log [\mathrm{NO}](\mathrm{M})$ at $\mathrm{pH} 8.0$ (circles), 8.6 (triangles), 8.9 (diamonds), and 9.2 (squares). The continuous lines were calculated according to Equation (3) with the following parameters: $\mathrm{pH}$ 8.0: $\mathrm{K}=4.4( \pm 0.5) \times 10^{-5} \mathrm{M}$ and $k_{\lim }=\left(6.7( \pm 0.7) \times 10^{-3} \mathrm{~s}^{-1}\right.$; $\mathrm{pH}$ 8.6: $K=5.6( \pm 0.7) \times 10^{-5} \mathrm{M}$ and $k_{\lim }=2.8( \pm 0.3) \times 10^{-2} \mathrm{~s}^{-1} ; \mathrm{pH} 8.9: K=5.6( \pm 0.7) \times 10^{-5} \mathrm{M}$ and $k_{\lim }=5.3( \pm 0.6) \times 10^{-2} \mathrm{~s}^{-1} ; \mathrm{pH} 9.2: K=5.7( \pm 0.6) \times 10^{-5} \mathrm{M}$ and $k_{\lim }=1.1( \pm 0.2) \times 10^{-1} \mathrm{~s}^{-1}$. (D) Dependence of $k_{\text {lim }}$ on the $\mathrm{OH}^{-}$concentration. The continuous line was calculated according to Equation (4) with $k_{\mathrm{OH}-}=6.9( \pm 0.7) \times 10^{3} \mathrm{M}^{-1} \mathrm{~s}^{-1}$. Where not shown, the error bars were smaller than the symbol.

\section{Discussion}

Nitrobindins constitute a new class of heme-proteins, characterized by a peculiar all- $\beta$-barrel structural arrangement [10-13]. Thus far, they have been found in M. tuberculosis, A. thaliana, and $H$. sapiens, where they are a $C$-terminal domain of the single-chain nuclear protein THAP4. Since the heme iron is stably in the Fe(III) form, their possible physiological role has been proposed to be NO sensing [10,11,13]; therefore, the characterization of the interaction of $\mathrm{Mt}-\mathrm{Nb}$ (III) and $\mathrm{Hs}-\mathrm{Nb}(\mathrm{III})$ with $\mathrm{NO}$ and of their pseudo-enzymatic role as NO scavengers is of the utmost importance. Of note, $M t-\mathrm{Nb}$ (III) and $\mathrm{Hs}-\mathrm{Nb}$ (III) react quickly with $\mathrm{NO}$, with the values of the second-order rate constant $\mathrm{NO}_{k}$ on being $1.8 \times 10^{6} \mathrm{M}^{-1} \mathrm{~s}^{-1}$ and $1.1 \times 10^{6} \mathrm{M}^{-1} \mathrm{~s}^{-1}$, respectively (Table 1); then, the Fe(III)-NO complex undergoes a slow reductive process, bringing about the formation of $\mathrm{HNO}_{2}$ and $\mathrm{Fe}$ (II)-NO through a series of $\mathrm{pH}$-dependent reactions (Scheme 1).

The data reported here allow us to draw the following conclusions: 
(i) The very fast $\mathrm{NO}$ binding kinetics of $\mathrm{Mt}-\mathrm{Nb}$ (III) and $\mathrm{Hs}-\mathrm{Nb}$ (III) [13], so as to be lost in the dead-time of the rapid-mixing stopped-flow apparatus at the employed NO concentrations (ranging between $2.5 \times 10^{-5}$ and $1.0 \times 10^{-3} \mathrm{M}$ ), reflect a specific feature of $\mathrm{Nbs}$, which is shared with NPs [9,31], since all other heme-proteins show an about 10 -fold slower reactivity (Table 1).

(ii) Despite the very different structural organization of the heme-proteins examined (all- $\beta$-barrel versus all- $\alpha$-helix structures) $[4-6,11,13,32-36]$, the values of $\mathrm{K}$ for $\mathrm{NO}$ binding to ferric heme-proteins are closely similar (ranging between $1.4 \times 10^{-5}$ and $2.1 \times 10^{-4} \mathrm{M}$ ) (present study and $[13,22-27,30]$ ) (Table 1 ). This suggests a balance between the NO association and dissociation rate constants among most heme-proteins, such that the energy barriers for ligand entry and exit are affected to the same extent by structural constraints.

(iii) The linear dependence of $\mathrm{k}$ on $\left[\mathrm{OH}^{-}\right]$indicates that no additional features are involved in the irreversible reductive nitrosylation of $M t-\mathrm{Nb}(\mathrm{III})$ and $H s-\mathrm{Nb}(\mathrm{III})$. Moreover, the values of $\mathrm{k}_{\mathrm{OH}-}$ for ferric heme-protein reductive nitrosylation range between $1.7 \times 10^{2} \mathrm{M}^{-1} \mathrm{~s}^{-1}$ and $6.9 \times 10^{3} \mathrm{M}^{-1} \mathrm{~s}^{-1}[13,22-27,30]$ (Table 1), possibly reflecting the different anion accessibility to the heme pocket and/or the heme-Fe(III) protein reduction potentials $[6,22,23,34,36-39]$. The close similarity of $\mathrm{k}_{\mathrm{OH}}$ - between all- $\beta$-barrel $\mathrm{Nbs}$ and all- $\alpha$-helical $\mathrm{Hb}$ indicates that the grossly different folding $[4,6,10,11,13,36,40,41]$ does not significantly affect anion accessibility to the heme pocket.

(iv) The rate of the conversion of heme-Fe(II)- $\mathrm{NO}^{+}$to heme-Fe(II) $+\mathrm{HNO}_{2}$ (Scheme 1C) represents the rate-limiting step of heme-protein reductive nitrosylation (present study and [22-28,30]). Of note, the $\mathrm{OH}^{-}$species catalyzes the conversion of $\mathrm{Mt}-\mathrm{Nb}(\mathrm{II})-\mathrm{NO}^{+}$to $\mathrm{Mt}-\mathrm{Nb}(\mathrm{II})+\mathrm{HNO}_{2}$ and of $\mathrm{Hs}-\mathrm{Nb}$ (II)-NO $\mathrm{NO}^{+}$to $\mathrm{Hs}-\mathrm{Nb}$ (II) $+\mathrm{HNO}_{2}$ much more efficiently than $\mathrm{H}_{2} \mathrm{O}\left(\mathrm{k}_{\mathrm{H} 2 \mathrm{O}} \sim 0 \mathrm{~s}^{-1}\right)$. This may reflect either the higher affinity of negatively charged ligands for ferric heme-proteins with respect to uncharged compounds and/or the deprotonation rate of the incoming ligand $[5,37,42]$.

(v) NO binding to ferrous heme-proteins (Scheme 1D) is known to also be very fast in Nbs [10]; therefore, it does not represent the rate-limiting step of the reductive nitrosylation process.

\section{Materials}

$H s-\mathrm{Nb}$ and $M t-\mathrm{Nb}$ were cloned, expressed, and purified as described previously [13]. The $H s-\mathrm{Nb}$ and $M t-\mathrm{Nb}$ concentration was determined spectrophotometrically using the following extinction coefficients at $\lambda_{\max }=407 \mathrm{~nm}: 100$ and $147 \mathrm{mM} \mathrm{cm}^{-1}$, respectively [13].

Gaseous NO (from Linde Caracciolossigeno S.r.l., Roma, Italy) was purified by flowing through a glass column packed with $\mathrm{NaOH}$ pellets, and then by passage through a trapping solution containing $20 \mathrm{~mL}$ of $5.0 \mathrm{M} \mathrm{NaOH}$ to remove traces of impurities; the NO pressure was $760.0 \mathrm{mmHg}$ [43]. The stock NO solution was prepared anaerobically by keeping the degassed $2.0 \times 10^{-3} \mathrm{M}$ bis-tris propane buffer solution ( $\mathrm{pH} 7.0)$ under $\mathrm{NO}$ in a closed vessel at $P=760.0 \mathrm{~mm} \mathrm{Hg}\left(T=20.0^{\circ} \mathrm{C}\right)$. The solubility of $\mathrm{NO}$ in the aqueous buffered solution is $2.05 \times 10^{-3} \mathrm{M}$, at $P=760.0 \mathrm{~mm} \mathrm{Hg}$ and $T=20.0^{\circ} \mathrm{C}$ [44]. The concentration of NO in the solution was determined, under anaerobic conditions and in the absence of the gaseous phase, by titration of ferrous horse heart Mb monitored by visible absorption spectroscopy [45].

All the other chemicals were obtained from Merck KGaA (Darmstadt, Germany). All products were of analytical grade and used without purification unless stated.

All the experiments were carried out with the SFM-20/MOS-200 rapid-mixing stopped-flow apparatus (BioLogic Science Instruments, Claix, France); the dead-time of the stopped-flow apparatus was $\sim 2 \mathrm{~ms}$ and the observation chamber was $1 \mathrm{~cm}$.

\section{Methods}

The reductive nitrosylation of $M t-\mathrm{Nb}(\mathrm{III})$ and $H s-\mathrm{Nb}$ (III) was investigated between $\mathrm{pH} 7.8$ and $9.2\left(5.0 \times 10^{-2} \mathrm{M}\right.$ bis-tris propane buffer), at $T=20.0^{\circ} \mathrm{C}$. The kinetics of the reductive nitrosylation of $\mathrm{Mt}-\mathrm{Nb}$ (III) and $\mathrm{Hs}-\mathrm{Nb}(\mathrm{III})$ were analyzed in the framework of the minimum reaction mechanism (Scheme 1) [22-29]. 
It is noteworthy that Scheme 1 indeed represents a redox enzymatic process, where NO scavenging is associated with the reduction of the heme-Fe(III) and nitrogen oxidation from $\mathrm{NO}$ and $\mathrm{HNO}_{2}$; thus, $\mathrm{NO}$ is the substrate and $\mathrm{HNO}_{2}$ is the product, with the whole chemical transformation being rate-limited by the $\mathrm{OH}^{-}$-dependent rate-limiting step $k_{\mathrm{OH}-}$.

The values of the apparent pseudo-first-order rate constant for the reductive nitrosylation (i.e., $k$ ) were obtained by rapid-mixing the $M t-\mathrm{Nb}$ (III) and $\mathrm{Hs}-\mathrm{Nb}$ (III) solution (final concentration ranging between $3.5 \times 10^{-6}$ and $4.1 \times 10^{-6} \mathrm{M}$ ) with the NO solution (final concentration ranging between $2.5 \times 10^{-5}$ and $1.0 \times 10^{-3} \mathrm{M}$ ) under anaerobic conditions. No gaseous phase was present. The reductive nitrosylation of $\mathrm{Mt}-\mathrm{Nb}$ (III) was monitored by single-wavelength stopped-flow spectroscopy between 380 and $450 \mathrm{~nm}$. The amplitude of the time courses was normalized at $407 \mathrm{~nm}$. The values of $k$ were obtained according to Equation (1) [22-29]:

$$
[M t-\mathrm{Nb}(\mathrm{III})]_{\mathrm{t}}=[\mathrm{Mt}-\mathrm{Nb}(\mathrm{III})]_{\mathrm{i}} \times \mathrm{e}^{-k \times t}
$$

The values of the equilibrium constant $K$ (corresponding to $\mathrm{NO}_{k_{\text {off }}} / \mathrm{NO}_{k_{\text {on }}}$ referring to Scheme $1 \mathrm{~A}$ ) and of the rate-limiting pseudo-first-order rate constant $k_{\text {lim }}$ (referring to Scheme 1B-D) were obtained from the dependence of $k$ on the NO concentration (i.e., [NO]), ranging between $2.5 \times 10^{-5}$ and $1.0 \times 10^{-3} \mathrm{M}$, according to Equations (2) and (3) [22-29]:

$$
k=\left(k_{\lim } \times \mathrm{NO}_{k_{\text {on }}} \times[\mathrm{NO}]\right) /\left(\mathrm{NO}_{k_{\text {off }}}+{ }^{\mathrm{NO}} k_{\text {on }} \times[\mathrm{NO}]\right)
$$

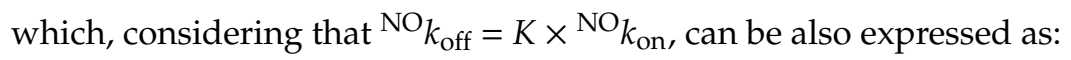

$$
k=\left(k_{\lim } \times[\mathrm{NO}]\right) /(K+[\mathrm{NO}])
$$

The values of the apparent second-order (i.e., $k_{\mathrm{OH}_{-}}$) and of the first-order (i.e., $k_{\mathrm{H} 2 \mathrm{O}}$ ) rate constants for the $\mathrm{OH}^{-}$- and $\mathrm{H}_{2} \mathrm{O}$-catalyzed conversion of $\mathrm{Mt}-\mathrm{Nb}$ (III)-NO $\mathrm{NO}^{+}$to $\mathrm{Mt}-\mathrm{Nb}$ (II), respectively, (Scheme $1 \mathrm{C}$ ) were determined from the dependence of $k_{\lim }$ on the $\mathrm{OH}^{-}$concentration (i.e., $\left[\mathrm{OH}^{-}\right]$) according to Equation (4) [22-29]:

$$
k=k_{\mathrm{OH}-} \times\left[\mathrm{OH}^{-}\right]+k_{\mathrm{H} 2 \mathrm{O}}
$$

\section{Conclusions}

The present results highlight the role of $M t-\mathrm{Nb}(\mathrm{III})$ and $H s-\mathrm{Nb}(\mathrm{III})$ as $\mathrm{NO}$ scavengers through the reductive nitrosylation reaction, which leads to the inactivation of two NO molecules. In spite of their much higher reactivity with $\mathrm{NO}$ to form the $\mathrm{Mt}-\mathrm{Nb}$ (III)- $\mathrm{NO}$ and $\mathrm{Hs}-\mathrm{Nb}$ (III)-NO species, respectively, the rate-limiting step for the conversion of $\mathrm{Fe}(\mathrm{II})-\mathrm{NO}^{+}$to $\mathrm{Fe}(\mathrm{II})$ and $\mathrm{HNO}_{2}$ is essentially similar to that of all- $\alpha$-helical heme-proteins, resulting only slightly faster than what was observed for human $\mathrm{Hb}$, Methanosarcina acetivorans Pgb, and Glycine max legHb (Table 1). This indicates that the structural determinants controlling these reactions are different. Indeed, while the very different NO reactivity reflects the diverse structural organization of the heme distal pocket of all- $\alpha$-helical and all- $\beta$-barrel heme-proteins, the similar reactivity of $\mathrm{OH}^{-}$is controlled by still undetermined factors. Reflecting the $\mathrm{NO} / \mathrm{O}_{2}$ ratio, the reductive nitrosylation of $\mathrm{Mt}-\mathrm{Nb}(\mathrm{III})$ and $\mathrm{Hs}-\mathrm{Nb}(\mathrm{III})$ occurs at high $\mathrm{NO}$ concentration, whereas the oxidation of $M t-\mathrm{Nb}$ (II)-NO and $H s-\mathrm{Nb}(\mathrm{II})-\mathrm{NO}$ takes place at high $\mathrm{O}_{2}$ levels. In this context, $\mathrm{Hs}-\mathrm{Nb}$ may act as a $\mathrm{NO} / \mathrm{O}_{2}$ sensor, modulating the transcriptional activity of THAP4.

Author Contributions: Conceptualization, M.C. and P.A.; methodology, G.D.S. and C.C.; investigation, G.D.S. and C.C.; writing-original draft preparation, P.A. and A.d.M.; writing-review and editing, P.A. and A.d.M.; supervision, M.C. and P.A.; funding acquisition, P.A. and A.d.M. All authors have read and agreed to the published version of the manuscript.

Funding: This research was partly funded by the grant Excellence Departments, MIUR, Italy (Articolo 1, Commi 314-337, Legge 232/2016).

Conflicts of Interest: The authors declare no conflict of interest. 


\section{References}

1. Brunori, M. Nitric oxide, cytochrome-c oxidase and myoglobin. Trends Biochem. Sci. 2001, 26, 21-23. [CrossRef]

2. Smith, L.J.; Kahraman, A.; Thornton, J.M. Heme proteins diversity in structural characteristics, function, and folding. Proteins 2010, 78, 2349-2368. [CrossRef]

3. Ascenzi, P.; Brunori, M. A molecule for all seasons: The heme. J. Porphyr. Phthalocyanines 2016, 20, 134-149. [CrossRef]

4. Perutz, M.F. Regulation of oxygen affinity of hemoglobin: Influence of structure of the globin on the heme iron. Annu. Rev. Biochem. 1979, 48, 327-386. [CrossRef] [PubMed]

5. Bolognesi, M.; Bordo, D.; Rizzi, M.; Tarricone, C.; Ascenzi, P. Non-vertebrate hemoglobins: Structural bases for reactivity. Prog. Biophys. Mol. Biol. 1997, 68, 29-68. [CrossRef]

6. Pesce, A.; Bolognesi, M.; Nardini, M. The diversity of 2/2 (truncated) globins. Adv. Microb. Physiol. 2013, 63, 49-78. [PubMed]

7. Andersen, J.F.; Weichsel, A.; Balfour, C.A.; Champagne, D.E.; Montfort, W.R. The crystal structure of nitrophorin 4 at $1.5 \AA$ resolution: Transport of nitric oxide by a lipocalin-based heme protein. Structure 1998, 6, 1315-1327. [CrossRef]

8. Weichsel, A.; Andersen, J.F.; Champagne, D.E.; Walker, F.A.; Montfort, W.R. Crystal structures of a nitric oxide transport protein from a blood-sucking insect. Nat. Struct. Biol. 1998, 4, 304-309. [CrossRef]

9. Andersen, J.F.; Ding, X.D.; Balfour, C.; Shokhireva, T.K.; Champagne, D.E.; Walker, F.A.; Montfort, W.R. Kinetics and equilibria in ligand binding by nitrophorins 1-4: Evidence for stabilization of a nitric oxide-ferriheme complex through a ligand-induced conformational trap. Biochemistry 2000, 39, 10118-10131. [CrossRef]

10. Bianchetti, C.M.; Blouin, G.C.; Bitto, E.; Olson, J.S.; Phillips, G.N., Jr. The structure and NO binding properties of the nitrophorin-like heme-binding protein from Arabidopsis thaliana gene locus At1g79260.1. Proteins 2010, 78, 917-931. [CrossRef]

11. Bianchetti, C.M.; Bingman, C.A.; Phillips, G.N., Jr. Structure of the C-terminal heme-binding domain of THAP domain containing protein 4 from Homo sapiens. Proteins 2011, 79, 1337-1341. [CrossRef] [PubMed]

12. De Simone, G.; Ascenzi, P.; Polticelli, F. Nitrobindin: An ubiquitous family of all $\beta$-barrel heme-proteins. IUBMB Life 2016, 68, 423-428. [CrossRef] [PubMed]

13. De Simone, G.; di Masi, A.; Vita, G.M.; Polticelli, F.; Pesce, A.; Nardini, M.; Bolognesi, M.; Ciaccio, C.; Coletta, M.; Turilli, E.S.; et al. Mycobacterial and human nitrobindins: Structure and function. Antioxid. Redox Signal. 2020, 33, 229-246. [CrossRef] [PubMed]

14. Ribeiro, J.M.; Hazzard, J.M.; Nussenzveig, R.H.; Champagne, D.E.; Walker, F.A. Reversible binding of nitric oxide by a salivary heme protein from a bloodsucking insect. Science 1993, 260, 539-541. [CrossRef]

15. Montfort, W.R.; Weichsel, A.; Andersen, J.F. Nitrophorins and related antihemostatic lipocalins from Rhodnius prolixus and other blood-sucking arthropods. Biochim. Biophys. Acta 2000, 1482, 110-118. [CrossRef]

16. Kondrashov, D.A.; Roberts, S.A.; Weichsel, A.; Montfort, W.R. Protein functional cycle viewed at atomic resolution: Conformational change and mobility in nitrophorin 4 as a function of $\mathrm{pH}$ and $\mathrm{NO}$ binding. Biochemistry 2004, 43, 13637-13647. [CrossRef]

17. Andersen, J.F. Structure and mechanism in salivary proteins from blood-feeding arthropods. Toxicon 2010, 56, 1120-1129. [CrossRef]

18. Knipp, M.; Ogata, H.; Soavi, G.; Cerullo, G.; Allegri, A.; Abbruzzetti, S.; Bruno, S.; Viappiani, C.; Bidon-Chanal, A.; Luque, F.J. Structure and dynamics of the membrane attaching nitric oxide transporter nitrophorin 7. F1000Research 2015, 4, 45. [CrossRef]

19. De Simone, G.; Ascenzi, P.; di Masi, A.; Polticelli, F. Nitrophorins and nitrobindins: Structure and function. Biomol. Concepts 2017, 8, 105-118. [CrossRef]

20. Weichsel, A.; Maes, E.M.; Andersen, J.F.; Valenzuela, J.G.; Shokhireva, T.K.; Walker, F.A.; Montfort, W.R. Heme-assisted $S$-nitrosation of a proximal thiolate in a nitric oxide transport protein. Proc. Natl. Acad. Sci. USA 2005, 102, 594-599. [CrossRef]

21. De Simone, G.; di Masi, A.; Polticelli, F.; Ascenzi, P. Human nitrobindin: The first example of an all- $\beta$-barrel ferric heme-protein that catalyzes peroxynitrite detoxification. FEBS Open Bio. 2018, 8, 2002-2010. [CrossRef] 
22. Hoshino, M.; Ozawa, K.; Seki, H.; Ford, P.C. Photochemistry of nitric oxide adducts of water-soluble iron(III) porphyrin and ferrihemoproteins studied by nanosecond laser photolysis. J. Am. Chem. Soc. 1993, 115, 9568-9575. [CrossRef]

23. Hoshino, M.; Maeda, M.; Konishi, R.; Seki, H.; Ford, P.C. Studies on the reaction mechanism for reductive nitrosylation of ferrihemoproteins in buffer solutions. J. Am. Chem. Soc. 1996, 118, 5702-5707. [CrossRef]

24. Herold, S.; Puppo, A. Kinetics and mechanistic studies of the reactions of metleghemoglobin, ferrylleghemoglobin, and nitrosylleghemoglobin with reactive nitrogen species. J. Biol. Inorg. Chem. 2005, 10, 946-957. [CrossRef] [PubMed]

25. Ascenzi, P.; Yu, C.; di Masi, A.; Gullotta, F.; De Sanctis, G.; Fanali, G.; Fasano, M.; Coletta, M. Reductive nitrosylation of ferric human serum heme-albumin. FEBS J. 2010, 277, 2474-2485. [CrossRef] [PubMed]

26. Ascenzi, P.; Pesce, A.; Nardini, M.; Bolognesi, M.; Ciaccio, C.; Coletta, M.; Dewilde, S. Reductive nitrosylation of Methanosarcina acetivorans protoglobin: A comparative study. Biochem. Biophys. Res. Commun. 2013, 430, 3001-3005. [CrossRef]

27. Ascenzi, P.; di Masi, A.; Tundo, G.R.; Pesce, A.; Visca, P.; Coletta, M. Nitrosylation mechanisms of Mycobacterium tuberculosis and Campylobacter jejuni truncated hemoglobins N, O, and P. PLoS ONE 2014, 9, e102811. [CrossRef] [PubMed]

28. Ascenzi, P.; De Simone, G.; Polticelli, F.; Gioia, M.; Coletta, M. Reductive nitrosylation of ferric human hemoglobin bound to human haptoglobin 1-1 and 2-2. J. Biol. Inorg. Chem. 2018, 23, 437-445. [CrossRef]

29. Ascenzi, P.; De Simone, G.; Sbardella, D.; Coletta, M. Reductive nitrosylation of ferric microperoxidase- 11 . J. Biol. Inorg. Chem. 2019, 24, 21-29. [CrossRef]

30. Ascenzi, P.; di Masi, A.; Gullotta, F.; Mattu, M.; Ciaccio, C.; Coletta, M. Reductive nitrosylation of ferric cyanide horse heart myoglobin is limited by cyanide dissociation. Biochem. Biophys. Res. Commun. 2010, 393, 196-200. [CrossRef]

31. Maes, E.M.; Weichsel, A.; Andersen, J.F.; Shepley, D.; Montfort, W.R. Role of binding site loops in controlling nitric oxide release: Structure and kinetics of mutant forms of nitrophorin 4. Biochemistry 2004, 43, 6679-6690. [CrossRef]

32. Bushnell, G.W.; Louie, G.V.; Brayer, G.D. High-resolution three-dimensional structure of horse heart cytochrome c. J. Mol. Biol. 1990, 214, 585-595. [CrossRef]

33. Ellis, P.J.; Appleby, C.A.; Guss, J.M.; Hunter, W.N.; Ollis, D.L.; Freeman, H.C. Structure of ferric soybean leghemoglobin a nicotinate at $2.3 \AA ̊$ resolution. Acta Crystallogr. D Biol. Crystallogr. 1997, 53, 302-310. [CrossRef] [PubMed]

34. Brucker, E.A.; Olson, J.S.; Ikeda-Saito, M.; Phillips, G.N., Jr. Nitric oxide myoglobin: Crystal structure and analysis of ligand geometry. Proteins 1998, 30, 352-356. [CrossRef]

35. Wardell, M.; Wang, Z.; Ho, J.X.; Robert, J.; Ruker, F.; Ruble, J.; Carter, D.C. The atomic structure of human methemalbumin at $1.9 \AA$ A. Biochem. Biophys. Res. Commun. 2002, 291, 813-819. [CrossRef] [PubMed]

36. Pesce, A.; Bolognesi, M.; Nardini, M. Protoglobin: Structure and ligand-binding properties. Adv. Microb. Physiol. 2013, 63, 79-96. [PubMed]

37. Beetlestone, J.G.; Adeosun, O.S.; Goddard, J.E.; Kushimo, J.B.; Ogunlesi, M.M.; Ogunmola, G.B.; Okonjo, K.O.; Seamonds, B. Reactivity difference between haemoglobins. Part XIX. J. Chem. Soc. Dalton Trans. 1976, 1251-1278. [CrossRef]

38. Perutz, M.F. Myoglobin and haemoglobin: Role of distal residues in reactions with haem ligands. Trends Biochem. Sci. 1989, 14, 42-44. [CrossRef]

39. Miele, A.E.; Santanché, S.; Travaglini-Allocatelli, C.; Vallone, B.; Brunori, M.; Bellelli, A. Modulation of ligand binding in engineered human hemoglobin distal pocket. J. Mol. Biol. 1999, 290, 515-524. [CrossRef]

40. Hargrove, M.S.; Barry, J.K.; Brucker, E.A.; Berry, M.B.; Phillips, G.N., Jr.; Olson, J.S.; Arredondo-Peter, R.; Dean, J.M.; Klucas, R.V.; Sarath, G. Characterization of recombinant soybean leghemoglobin a and apolar distal histidine mutants. J. Mol. Biol. 1997, 266, 1032-1042. [CrossRef]

41. di Masi, A.; De Simone, G.; Ciaccio, C.; D’Orso, S.; Coletta, M.; Ascenzi, P. Haptoglobin: From hemoglobin scavenging to human health. Mol. Asp. Med. 2020, 73, 100851. [CrossRef] [PubMed]

42. Giacometti, G.M.; Ascenzi, P.; Bolognesi, M.; Brunori, M. Reactivity of ferric Aplysia myoglobin towards anionic ligands in the acidic region. Proposal for a structural model. J. Mol. Biol. 1981, 146, 363-374. [CrossRef] 
43. Barbosa, R.M.; Lopes Jesus, A.J.; Santos, R.M.; Pereira, C.L.; Marques, C.F.; Rocha, B.S.; Ferreira, N.R.; Ledo, A.; Laranjin, J. Preparation, standardization and measuremet of nitric oxide solutions. Glob. J. Anal. Chem. 2011, 2, 272-284.

44. Antonini, E.; Brunori, M. Hemoglobin and Myoglobin in Their Reactions with Ligands; North-Holland Publishing Co.: Amsterdam, The Netherland, 1971.

45. Ascenzi, P.; Brunori, M.; Pennesi, G.; Ercolani, C.; Monacelli, F. Equilibrium and kinetic study of nitric oxide binding to phthalocyaninatoiron(II) in dimethyl sulphoxide. J. Chem. Soc. Dalton Trans. 1987, 369-371. [CrossRef]

Publisher's Note: MDPI stays neutral with regard to jurisdictional claims in published maps and institutional affiliations.

(C) 2020 by the authors. Licensee MDPI, Basel, Switzerland. This article is an open access article distributed under the terms and conditions of the Creative Commons Attribution (CC BY) license (http://creativecommons.org/licenses/by/4.0/). 